Prof. dr. Šefik Kurdić

\title{
DA'VETSKA ANGAŽIRANOST ASHABA
}

Sažetak

Ovaj rad obrađuje angažman ashaba na polju da've, ističući konkretne primjere njihovog da 'vetskog angažmana.

Rad je posebnu pažnju posvetio da'vetskom angažmanu četverice halifa, te $i$ ostalih ashaba, između kojih je istakao angažiranost Bilal b. Rebaha, Suhejba er-Rumija, Sa'd b. EbiVekkasa i drugih.

Ashabi Allahovog poslanika Muhammeda, sallallahu 'alejhi ve sellem, željeli su sreću $i$ duhovno zadovoljstvo koje su osjećali podijeliti sa drugima. Upravo ta nesebičnost $i$ briga za drugima $i$ pokušaj da ih se izbavi iz zablude bili su i ostali njihova konstantna opsesija.

Namjera ovoga rada je da nekoliko navedenih primjera potakne na ozbiljniji i djelotvorniji da'vetski angažman.

Uvod

Svi ashabi Allahovog Poslanika, s.a.v.s., bili su časni, pošteni i pravedni. To je generacija koju je Allah Plemeniti u svojoj časnoj Knjizi pohvalio, naglasivši: Vi ste narod najbolji od svih koji se ikada pojavio: tražite da se čine dobra djela, a od nevaljalih odvraćate, $i u$ Allaha vjerujete! ${ }^{l}$ Iako se ovaj ajet odnosi na cijeli ummet Muhammeda, s.a.v.s, i na svako vrijeme, ipak Ibn Kesir smatra da se njime posebno potcrtava prva generacija muslimana $i$ njihovo vrijeme. ${ }^{2}$ Osim Kur'anom, to je potvrđeno i sunnetom i idžma'om.

Allahov Poslanik, s.a.v.s., u hadisu koji prenosi Abdurrahman b. Avf, r.a., izdvojio je desetericu ashaba, obećavši im Džennet, pa su to, po mnogima, ujedno i najvredniji ashabi. $U$ tom je hadisu Vjerovjesnik, s.a.v.s., spomenuo desetericu, i to su: Ebu-Bekr es-

\footnotetext{
${ }^{1}$ Alu 'Imran, 110.

${ }^{2}$ Uporedi: Tefsir Ibn Kesira, Izdanje Visokog saudijskog komiteta za pomoć BiH, str. 221.
} 
Siddik, Omer b. el-Hattab, Osman b. Affan, Ali b. ebi Talib, Talha b. Ubejdillah, Ez-Zubejr b. el-Avvam, Se'id b. Zejd, Ebu Ubejde b. elDžerrah, Sa'd b. ebi Vekkas i Abdurrahman b. Avf. ${ }^{3}$

Inače su, najvredniji ashabi, čak najvrednija stvorenja, nakon Allahovog Poslanika, s.a.v.s., kako ističe Ibn Kesir: Ebu Bekr, Omer, Osman i Alija, r.a. To je stav i muhadžira i ensarija. ${ }^{4}$

Da'vetski angažman ashaba bio je paradigmatičan svim generacijama koje su dolazile nakon njih. Ništa ih nije moglo spriječiti da Allahovu riječ dostave drugima. Nije onda čudo kakvo im je mjesto Allah dao, kao što tvrdi Poslanik islama, s.a.v.s., u jednoj predaji: Doista je Allah - izuzevši poslanike - dao prednost mojim ashabima nad ostalim ljudima! $!^{5}$

Ashabi su sve svoje mogućnosti i potencijale upotrijebili da bi dostavili i afirmirali istinu. Na tom putu su žrtvovali sve: i imetak, i život, i vrijeme... To je, uistinu, u povijesti ljudskog roda jedinstvena generacija, koja se sa takvom snagom, pregalaštvom i savješću, nije ponovila. Nije, onda, ni čudo što su napravili takav uspjeh o kojem drugi mogu samo sanjati!

\section{Angažiranost hulefai-r-rašidina}

Prva četverica halifa su svoj časni zadatak vođenja islamske države i nesebičnog zalaganja na prezentiranju islama i njegovih ideja sprovodili svega 30 godina, od 10. do 40 . god. po Hidžri, upravo onako kako je Allahov Poslanik, s.a.v.s., najavio u predaji koju prenosi Sefine, r.a., a koja glasi: Hilafet će trajati trideset godina, a onda će nastati monarhija!

U drugoj predaji koju prenosi Ubejde b. el-Džerrah, r.a., Vjerovjesnik, s.a.v.s., rekao je: Vaša vjera je počela poslanstvom $i$ milošću, nastaviće se hilafetom i milošću a onda će nastupiti monarhija i despotizam!

\footnotetext{
${ }^{3}$ Hadis bilježe Tirmizi i Ahmed.

${ }^{4}$ Ibn Kesir, Ihtisaru ulumi-1-hadis , str.173-174 (štampano zajedno sa komentarom Ahmeda Muhammeda Šakira).

${ }^{5}$ Hadis bilježi El-Bezzar sa pouzdanim lancem prenosilaca.

${ }^{6}$ Predaja je vjerodostojna. Bilježe je Ebu-Davud, Tirmizi, Nesai, Ibn Madže, Ahmed i Ibn Hibban.

${ }^{7}$ Hadis je sa dobrim lancem prenosilaca. Bilježi ga El-Bezzar.
} 
Iako je period vladavine hulefai-r-rašidina bio relativno kratak, ipak je on obilovao izuzetnim da'vetskim pokretom koji je obilježio to razdoblje. Misionarski angažman, posebno u vrijeme prve trojice halifa, bio je neprocjenjivog značaja za da'vu u cjelini.

$\mathrm{U}$ to vrijeme zastava islama zavihorila se u mnogim novim područjima da bi taj zalet, donekle, bio zaustavljen za vrijeme hilafeta Alije b. ebi Taliba, r.a., zbog poznatih unutrašnjih razmimoilaženja i sukoba među muslimanima.

Ebu Bekr, r.a.

Ebu Bekr b. ebi Kuhafe es-Siddik, r.a., ${ }^{8}$ iako je predvodio islamsku državu samo dvije godine i tri mjeseca, napravio je izuzetan podvig na političkom, vojnom, ekonomskom, socijalnom ali još veći na da'vetskom planu! On je svojom hrabrošću i pronicljivošću savladao odmetnike, sredio račune sa onima koji su odustali plaćati zekjat i spremio vojsku na čelu sa Usame b. Zejdom, r.a. Tako je proširio ideju islama u nove krajeve i područja. Cilj usmjeravanja boraca u različita područja bio je jasan: da'vetsko djelovanje i dominacija Allahove riječi na Zemlji!

Takvi uspjesi, posebno na da'vetskom planu, mogu se tumačiti pronicljivošću, blagošću i iskrenošću Ebu Bekra es-Siddika, r.a. Za njega brojni izvori tvrde da je bio inteligentan, privlačan, prijatan, elegantan, blag i drag. On je najbolje znao rodoslovlje Kurejšija. Znao je da čita i piše. Mnogi su se trudili da budu uz njega zbog znanja, poštenja u trgovini i prijatnosti druženja s njim. ${ }^{9}$

On je plijenio srca ljudi svojom pojavom, znanjem i suptilnošću. Otuda je i sam Allahov Poslanik, s.a.v.s., izjavio, da bi kada bi sebi uzimao prisnog prijatelja (halila)- uzeo, prije svih, Ebu Bekra es-Siddika! ${ }^{10}$

Nije se čuditi što je Poslanik, s.a.v.s., znajući za njegove visoke moralne vrline, najprije Ebu Bekru ponudio da prihvati islam.

\footnotetext{
${ }^{8}$ Puno mu je ime: Abdullah b. Osman b. Amr b. Omer b. Ka'b b. Sa'd b. Tejm b. Murre b. Ka'b b. Luejj b. Galib. Rođen je dvije i po godine nakon tzv. Godine slona. Umro je 13. god. po Hidžri u 63. godini života (vidi: Dr. Faruk Hammade, u knjizi: Fadailu-s-sahabe Imama Nesaije, str. 51).

9 Vidi: Ibn Hišam, Poslanikov životopis, str. 47 i Hilmi Ali Ša’ban, Ashabi Allahovog Poslanika, str. 10.

${ }^{10}$ Hadis bilježe Buhari, Muslim, Tirmizi, Ahmed i dr.
} 
Ovaj Poslanikov, s.a.v.s., izbor pokazao se perfektnim, jer će Ebu Bekr, r.a., svojom istančanom profinjenošću i suptilnim metodama pravoga da'ije uvesti u islam svu mekkansku elitu, kao što su, recimo: Osman b. Affan, Abdurrahman b. Avf, Talha b. Ubejdillah, Zubejr b. Avvam, Sa'd b. ebi Vekkas, Ebu Ubejde b. el-Džerrah i dr. ${ }^{11}$

Ebu Bekr, r.a., nije se zadovoljio samo teoretskim pozivanjem u islam, već je u taj poziv utkao i svoju kompletnu ličnost, pa čak založio i sav svoj imetak! Onog dana kada je prešao na islam, u njegovoj kući se zadesilo 40.000 dirhema. Sve ih je podijelio na Allahovom putu! Učinio je to, uglavnom, oslobađajući nemoćne robove koje su maltretirali robovlasnici samo zato što su postali muslimani. Aiša, r.a., prenosi da je Ebu Bekr, r.a., tada oslobodio sedam robova koji su bili pod velikom torturom i mučeni! ${ }^{12}$

$\mathrm{Na}$ planu širenja islama i afirmiranja istine dijelio je sve što je imao. Omer b. el-Hattab, r.a., pripovijeda zanimljiv slučaj u kojem spominje da im je Allahov Poslanik, s.a.v.s., naredio da nešto, u ime Allaha, podijele, pa je Omer, r.a., pokušao, bar tada, preteći Ebu Bekra, r.a, pa je pola svog imetka podijelio na Allahovom putu! Kada ga je Vjerovjesnik, s.a.v.s, upitao: Šta si ostavio svojoj porodici?, odgovorio je: Ostavio sam im isto toliko! Ebu Bekr, r.a., došao je i sa sobom donio sve što je imao i sve to podijelio na Allahovom putu. Poslanik, s.a.v.s., upitao ga je: Ebu Bekre, a šta si ostavio svojoj porodici? Odgovorio je: Ostavio sam im Allaha i Njegovog Poslanika! Nakon ovoga je Omer, r.a., zaključio : Nikada ga ni u čemu neću moći preteći! $^{13}$

Toliko je Ebu Bekr, r.a., dijelio svoj imetak u želji da što snažnije potpomogne istinu da je Vjerovjesnik, s.a.v.s., izjavio u predaji koju prenosi Ebu Hurejre, r.a.: Ničiji mi imetak nije koristio kao imetak Ebu Bekra! Kada je to čuo, Ebu Bekr, r.a., zaplakao je i rekao: A kome ja i moj imetak pripadamo, ako ne tebi, Allahov Poslaniče?! ${ }^{14}$

Nije onda čudo što brojni autori smatraju da je sebebinuzul/razlog objavljivanja kur'anskih ajeta: a od nje će daleko biti

\footnotetext{
${ }^{11}$ Vidi: Ibn Hišam, cit. djelo, str. 47; Munir Muhammed Gadban, El-Menhedžu-1hareki li-s-sireti-n-nebevijje, 1/22 i Hilmi Ali Ša'ban, Ashabi Allahovog Poslanika, str. 11.

${ }^{12}$ Bilježi Ibn Asakir. Vidi: Es-Sujuti, Tarihu-1-hulefai, str. 36.

${ }^{13}$ Hadis je autentičan. Bilježe ga Ebu Davud i Tirmizi.

${ }^{14}$ Hadis bilježi Ahmed.
} 
onaj koji se bude Allaha bojao, onaj koji bude dio imetka svoga udjeljivao, da bi se očistio, ne očekujući da mu se zahvalnošću uzvrati, već jedino da bi naklonost Gospodara svoga Svevišnjeg stekao, i on će, zbilja, zadovoljan biti! ${ }^{15}$ upravo bilo Ebu Bekrovo, r.a., nesebično dijeljenje na Allahovom putu u cilju potpomaganja Istine. $^{16}$

Ako analiziramo Ebu Bekrov, r.a., život, vidjećemo da je Ebu Bekr, r.a., bio poseban karakter. Otkrićemo da on, čak, ni u predislamskom periodu, nije obožavao kipove niti je pio alkohol! ${ }^{17}$

$\mathrm{Na}$ temelju samo djelića onoga što smo iznijeli iz života Ebu Bekra, r.a., retoričko postaje pitanje: Otkuda toliki uspjeh na političkom, vojnom, ekonomskom, socijalnom, a posebno da'vetskom planu i otkuda takav šarm koji je osvajao i plijenio ljudska srca?!

Možemo samo reći da je Ebu Bekr, r.a., bio inspiriran Kur'anom i sunnetom Allahovog Poslanika, s.a.v.s., i da su svi njegovi postupci emanirali iz njegovog bića ispunjenog stabilnim, nepatvorenim i nesalomljivim imanom, koji je najbolje odslikao Omer, r.a., kada je kazao: Kada bi se mjerio iman Ebu Bekra i iman svih stanovnika Zemlje, prevagnuo bi iman Ebu Bekra!!!'

\footnotetext{
${ }^{15}$ El-Lejl, str. 17-21.

${ }^{16}$ Ove predaje bilježe: Taberani, Taberi, El-Bezzar, Ibn ebi Hatim i dr.

17 Vidi o tome: Tarihu-1-hulefai, str. 30 i Sabir Abduh Ibrahim, Ebu Bekr, prvi halifa, str. 12 .

${ }^{18}$ Ovu predaju bilježi Bejheki u Šu'abu-1-imanu.
} 
Omer, r.a.

Omer b. el-Hattab, r.a., ${ }^{19}$ uspio je ojačati i proširiti islamsku državu u vrijeme dok ju je predvodio deset godina, pet mjeseci i dvadeset $\mathrm{i}$ jedan dan ${ }^{20}$, a na planu da've napraviti velike pomake $\mathrm{i}$ izuzetne rezultate. Ustvari, to je bio kontinuiran nastavak briljantne da'vetske aktivnosti njegovog prethodnika Ebu Bekr es-Siddika, r.a. On je samo znalački nastavio Ebu Bekrove, r.a, aktivnosti i napravio takve poteze koji će mu osigurati lijep spomen sve do Sudnjeg dana!

Ono što je značajno primijetiti u slučaju ovog velikog ashaba i pravednog halife jeste da je on svoj politički, društveni i vjerski autoritet koristio za afirmiranje da'vetskih aktivnosti. Njegov prepoznatljivi idžtihad bio je, primjetno je, u službi da've, a osvajanje novih područja nije bilo ništa drugo nego svojevrsna da'vetska prezentacija koju je direktno potaknuo Omer, r.a.. ${ }^{21}$

Omer, r.a., istim žarom nastavlja započetu misiju vojnim pohodima, upravo onako kako je činio njegov prethodnik Ebu Bekr, r.a.

${ }^{19}$ Njegovo puno ime je: Omer b. el-Hattab b. Nufejl b. Abdi-1-'Uzza b. Rijah b. Abdullah b. Kart b. Rezah b. Adijj b. Ka'b b. Le'ujj b. Galib, Emiru-1-mu'minin, Ebu Hafs, el-Kureši el-'Adevi, el-Faruk. Iz njegovog imena se vidi da vodi prijeklo od plemena Adijj b. Ka'b, dakle, ogranka kurejšijskog plemena Adnan.

S obzirom da je njegovo pleme bilo siromašno, Omer, r.a., pokušavao je to prevazići putem znanja. Tako se posvetio znanju i iščitavanju pisane mudrosti, pamtio je stihove i prozu tog vremena. Bio je među malobrojnim koji su znali čitati i pisati.

Omer, r.a, od djetinjastva je volio jahanje konja, streljaštvo, mačevanje i učestvovanje na raznim takmičenjima. Sve takmičare je pobjeđivao. Nije ni čudo, budući da je bio visok preko dva metra, jake tjelesne konstrukcije i čvrstih mišića.

$\mathrm{Na}$ islam je prešao 6. god. po Objavi, nakon što je islam primilo 45 muškaraca i 21 žena. Tada je imao, po Ibnu-l-Dževziju, 27 godina, a po Sujutiju - 35 .

Ubio ga je vatropoklonik Ebu Lu'lu' el-Medžusi, na sabah-namazu, 23. god. po Hidžri, a ukopan je početkom mjeseca muharrema 24. god. po Hidžri. Omeru, r.a., tada su bile 63 godine. Vidi šire: Ibnu-1-Dževzi, Menakibu emiri-l-mu'minine Omer b. el-Hattab, str. 9-260; Ibn Hadžer, El-Isabe fi temjizi-s-sahabe, 2/518-519; EsSujuti, Tarihu-l-hulefai, str.101-138 i Hilmi Ali Ša'ban, Ashabi Allahovog Poslanika, str. 29-49.

${ }^{20}$ Vidi: Ibnu-l-Dževzi, Menakibu Emiri-l-mu'minine Omer b. el-Hattab, str. 231.

${ }^{21}$ O tome vidi izvanrednu studiju: Omer ed-da'ijjetul-1-mudžtehid, u knjizi: EdDa'vetu-l-islamijjetu fi 'ahdi Emiri-l-mu'minine Omer b. el-Hattab iz pera Husni Muhammed Ibrahima Gajtasa, str. 87-144, u izdanju poznate izdavačke kuće ElMektebu-1-islami, 1985. god. 
Odlazak vojnih ekspedicija u područja do kojih nije stigla ideja islama doprinio je da se tamošnji narodi upoznaju sa islamom, tako da se bilježi značajno islamiziranje određenih područja bez ratnih sukoba, čemu je uveliko doprinio sam halifa Omer, r.a., koji je fascinantnom mudrošću odabirao ne samo velike junake nego i mudre $\mathrm{i}$ iskusne da'ije, što su djelotvornim metodama prezentirali islam na način koji osvaja srca u područjima u koja su dolazilit ${ }^{22}$

Analizirajući Omera, r.a., i njegov život dolazi se do konstatacije da je takav briljantan uspjeh i na vojnom i na da'vetskom planu bio očekivan! Omera, r.a., zbog njegove odlučnosti, karaktera i borbe za istinu, sam Poslanik islama, Muhammed, s.a.v.s., nazvao je El-Faruk/Onaj koji rastavlja istinu od neistine! ${ }^{23}$ Ibn Abbas prenosi predaju u kojoj se kaže da su se stanovnici nebesa obradovali Omerovom, r.a., prelasku na islam! ${ }^{24}$

Posebno se Omerovom, r.a., prelasku na islam obradovala mala skupina muslimana koja je bila žestoko maltretirana i mučena. Tako Abdullah b. Mes'ud, r.a., nakon njegovog prelaska na islam, izjavljuje: Omerovo primanje islama bila je pomoć, njegova hidžra bila je pobjeda, a njegova vladavina bila je milost. Mi nismo mogli klanjati kod Kjabe sve dok Omer nije primio islam! Tek njegovim prelaskom na islam, mogli smo to činiti! ${ }^{25}$

Iman i bogobojaznost bile su prepoznatljive crte tog islamskog velikana. Dovoljno je samo spomenuti da je, učeći ajete, iz strahopoštovanja prema Gospodaru svemira plakao sve dok ne bi pao, pa bi ga ljudi obilazili kao bolesnika! $!^{26}$ Od plakanja je, kao posljedicu, imao dvije crne crte na licu! $!^{27}$ Ibnu-1-Dževzi navodi da je znao plakati na sabah-namazu, tako da bi se njegovi jecaji čuli i u trećem saffu! $!^{28}$

\footnotetext{
${ }^{22} \mathrm{O}$ fascinantnim da’vetskim metodama ashaba koje je Omer, r.a., uputio u ove krajeve vidi opširno u spomenutoj knjizi Hunija Gajtasa, u poglavlju: El-Futuhatu-1islamijjetu fi 'ahdi Omer b. el-Hattab ve eseruha fi nešri-d-da've, str. 211-296.

${ }^{23}$ Vidi: Ibn-1-Dževzi, nav. djelo, str.19 i 26 i Tarihu-1-hulefai, str. 107.

${ }^{24}$ Predaju bilježe: Ibn Madže i Hakim od Ibn Abbasa, r.a. Vidi, također: Ibn Sa'd, Et-Tabekat, 3/269; Ibnu-1-Dževzi, str. 18 i Tarihu-l-hulefai, str. 107.

25 Ibnu-l-Dževzi, str. 18-19, Tarihu-l-hulefai, str. 107 i Hilmi Ali Ša’ban, Ashabi Allahovog Poslanika, str.33.

${ }^{26}$ Menakibu Emiri-l-mu'minine Omer b. el.Hattab, str. 168.

${ }^{27}$ Mahmud Šakir, Et-Tarihu-l-islami, 3/202 i Ahmed Ferid, Bistro more pobožnosti i suptilnosti, str. 219.

${ }^{28}$ Menakibu Emiri-1-mu'minine, str. 168.
} 
O njegovoj bogobojaznosti i odgovornosti Ibnu-1-Dževzi navodi i sljedeće primjere:

- On je ložio vatru i stavljao ruku u nju, sam sebi govoreći: Sine Hattabov, možeš li ovo izdržati?!

- Uzeo je slamku u svoje ruke i rekao: Da sam Bogdo ova slamka!

- Jednom prilikom je rekao: Kada bi mazga na sjeveru Iraka slomila nogu (zbog lošeg puta), ja bih za nju odgovarao na Sudnjem danu!!! $!^{29}$

Nije onda čudo što je Allahov Poslanik, s.a.v.s., vidio u snu ljude koji imaju košulje koje im sežu do grudi, drugi ispod a Omer, r.a., košulju toliko dugu da se vuče za njim. Na upit ashaba šta to znači, Poslanik, s.a.v.s., odgovorio je da to simbolizira vjeru! ${ }^{30}$

Ako prelistamo islamsku literaturu, naći ćemo brojne primjere Omerove, r.a., skromnosti i zuhda. Pogledajmo:

- Bio je halifa, a na njegovom ogrtaču bilo je 12 zakrpa!

- Jeo je hljeb od ječma sve do smrti!

- Dok je bio halifa, njegova hrana sastojala se od hljeba i ulja, a hrana muslimana od hljeba i mesa!

- Gledajući jednom prilikom lijepo janje, izjavio je: Da se ne bojim odgovornosti, naredio bih da nam se ispeče ovo jagnje!

- Prohtjelo mu se da kupi nešto što je koštalo samo jedan dirhem, pa je odugovlačio sa kupovanjem čitavu godinu! ${ }^{31}$

Omer, r.a, slovio je kao najpravedniji vladar u historiji. Ako pogledamo samo neke primjere, $u$ to ćemo se doista i uvjeriti:

- Tražio je da sluge jedu s njim!

- Jednom prilikom obratio se svojoj mazgi riječima: Bojim se da ne odgovaram za tebe!

- Jednog čovjeka je udario zato što je pretovario devu!

- Jednom prilikom je ostarjeli Židov tražio osnovne potrepštine od njega, a on ga je prvo odveo svojoj kući i dao mu šta je mogaoa, onda poslao u državnu blagajnu i

\footnotetext{
${ }^{29}$ Cit. djelo, str. 161-162.

${ }^{30}$ Ovu autentičnu predaju Ebu Se'ida el-Hudrija, r.a., bilježi Buhari u svom Sahihu.

${ }^{31}$ Ove primjere vidi: Ibnu-l-Dževzi, cit. djelo, str. 137-146 i M. Šakir, cit. djelo, $3 / 203$.
} 
naredio da se taj čovjek osigura, jer, zbog starosti, nije mogao zarađivati!

- Sin egipatskog namjesnika Amra b. el-Asa, r.a., takmičio se $\mathrm{s}$ jednim nemuslimanom, pa ga je taj nemusliman pobijedio, na što ga je namjesnikov sin udario. Omer, r.a., saznavši za to, naredi da oba dođu u Medinu. Kada su došli do njega, zahtijevao je da nemusliman udari namjesnikovog sina kao što je i namjesnikov sin njega udario! $!^{32}$

- Njegovu skromnost i težnju za pravdom na najbolji način će ilustrirati primjer koji je zabilježi u islamskim izvorima a u kojem se kaže da je izaslanik Kisre, jedanput, kada je dolazio u Medinu, pitao za kraljev dvorac, na što su mu muslimani odgovorili da oni niti imaju kralja - niti imaju dvorce. Rekli su mu da imaju halifu, koji stanuje u običnoj kućici u kakvoj i ostali muslimani stanuju. Omera, r.a., nađu kako spava u hladu pod jednom palmom. Kada je izaslaniku rečeno da je to vladar tada najmoćnije države, ovaj se zaprepastio pitajući muslimane za tjelohranitelje Omera, r.a., jer ih ne vidi kod njega! Kada se izaslanik doista uvjerio da je to Omer, r.a., i da nema ni jednog tjelohranitelja uz sebe, izrekao je poznatu rečenicu: Pravdu si uspostavio, pa si, zato, mirno zaspao! ${ }^{33}$

To je Omer, r.a.! Čovjek koji je naređivao pravdu ali je, u isto vrijeme, bio najpravedniji! Kažu da je ovaj izaslanik, vrlo brzo nakon susreta sa Omerom, r.a., prihvatio islam! Njegova pravda bila je prekretnica za nemuslimane u brzom prihvatanju islama i jedna od bitnih da'vetskih komponenti koje su krasile ovog velikog ashaba!

Omer, r.a., mogao je biti takav zahvaljujući znanju koje je posjedovao, a koje je, opet, zadobio u Poslanikovoj, s.a.v.s., školi! Abdullah b. Mes'ud, r.a., rekao je: Kada bi se na jedan tas vage stavilo znanje Omerovo, a na drugi tas znanje čitavog svijeta, prevagnulo bi Omerovo znanje! Smrću Omerovom nestalo je devet desetina znanja! ${ }^{34}$ Imam El-Gazali spominje da je Ibn Mes'ud, r.a.,

\footnotetext{
${ }^{32}$ Vidi ove primjere: Ibnu-l-Dževzi, str. 96, 97 i 103 i M. Šakir, cit. djelo, 3/202, 207 i 211.

${ }^{33}$ Vidi ovaj primjer: Hilmi Ali Ša’ban, cit. djelo, str. 48-49.

${ }^{34}$ Ibnu-1-Dževzi, cit. djelo, str. 247.
} 
tada bio upitan: Kako tako tvrdiš, a među nama živi još toliki broj poznatih ashaba?! Odgovrio je: Ja pod tim ne podrazumijevam fetve, fikhske propise i obične informacije. Omer je imao znanje o Allahu $i$ najbolje Ga je spoznao! $!^{35}$

Nije onda čudo što ga je šejtan zaobilazio i, kada bi ga primijetio, bježao drugim putem! ${ }^{36}$ Također, nikoga ne treba čuditi što je dvorac u Džennetu, vanredne ljepote, pripremljen, kako navodi Poslanik islama, s.a.v.s., upravo za tog velikana! ${ }^{37}$

Ako se još kaže da je Allahov Poslanik, s.a.v.s., izjavio u hadisu koji prenosi Ukbe b. Amir, r.a.: Kada bi bilo vjerovjesnika nakon mene, onda bi to bio Omer b. el-Hattab. ${ }^{38}$, onda doista ne treba ništa više reći o tom velikom čovjeku, hrabrom junaku i izuzetnom prijatelju Allahovog Poslanika, s.a.v.s., a uz to, vanrednom da'iji, koji je svojom odanošću Allahovoj vjeri, svojom mudrošću i lijepim metodama načinio fascinantne rezultate!

Osman, r.a.

U periodu Osmanovog, r.a., hilafeta ${ }^{39}$ nastavljena je da'vetska aktivnost - istim žarom kao što je bilo i za dvojice ranijih halifa.

${ }^{35}$ Uporedi: Ihjau ulumi-d-din, 1/40.
${ }^{36}$ Predaju bilježe Taberani i Darekutni. Vidi, također, Sujuti, cit. djelo, str. 111.
${ }^{37}$ Hadis je autentičan. Bilježe ga Buhari, Muslim, Tirmizi i dr.
${ }^{38}$ Hadis bilježe Tirmizi i Hakim ocjenjujući ga vjerodostojnim. Hadis, takode prenose Taberani, posredstvom Ebu Se'ida el-Hudrija, r.a., i Ibn Asakir, posredstvom Ibn Omera, r.a.

${ }^{39}$ Njegovo ime je Osman b. Affan b. ebi el-'As b Umejje b. Abdi Šems b. Abdi Menaf b. Kusajj b. Kilab b. Murre b. Ka’b b. Lu’ejj b. Galib Ebu Amr el-Kureši elEmevi. Rođen je u Taifu, 47. god. prije Hidžre. Bio je mlađi od Poslanika, s.a.v.s., skoro šest godina. Među prvima je primio islam, posredstvom Ebu Bekra, r.a., i to prije nego su se ashabi počeli skupljati u kući Erkama, r.a. Ibn Ishak tvrdi da je 4. primio islam. Činio je dvije hidžre: prvu u Abesiniju, sa svojom suprugom, a kćerkom Allahovog Poslanika, s.a.v.s., Rukajjom, r.a., a drugu u Medinu. Poslije smrti Rukajje, r.a., oženio se i drugom Poslanikovom, s.a.v.s, kćerkom Ummi Kulsum, r.a. Bio je na čelu islamske države skoro 12 godina. Pao je u svojoj kući kao šehid, ubijen rukom osvetnika dok je učio Kur'an, 35. god. po Hidžri kada je napunio 82 godine života. (Pogledaj njegovu biografiju:El-Bidaje ve-n-nihaje, 7/160-207; El-Isabe fi temjizi-s-sahabe, 2/462463; Tarihu-l-hulefai, str. 138-155, Et-Tarihu-1-islami, 3/217-248, Hilmi Ali Ša’ban, cit. djelo, str, 51-70, dr. Faruk Hamade, u knjizi: Imam en-Nesai, Fadailu-s-sahabe, str. 67-68 i Muhammed Muveffak Selima, Deseterica kojima je obećan Džennet, str. 21-27) 
Slobodan i djelotvoran da'vetski angažman ovisi o slobodi govora, kretanja i drugih vrsta komunikacije. To je Osman, r.a., veoma dobro znao, pa je nastavio oslobađati nova područja i uklanjati jarmove zuluma koji su bili natureni narodima u tim područjima, kako bi, na taj način, mogli sasvim slobodno i dostojanstveno izabrati vjeru koju hoće i kodeks ponašanja koji im, doista, imponira.

Osman, r.a., uz područja koja su osvojena u vrijeme Omera, r.a., širi front vojnih aktivnosti, ali i da'vetskih djelovanja. ${ }^{40}$ To je, ujedno, bila i prilika brojnim ashabima da iskažu afinitet za da'vu, što su oni na najbolji način i pokazali!

Izuzetnom uspjehu da'vetske misije Osmana, r.a, svakako je doprinjela njegova izuzetna blagost. On je bio itekako omiljen i cijenjen u narodu, a bio je i jedan od najljepših ashaba. Ibn Asakir navodi predaju Abdullaha el-Mazinija u kojoj se ističe: Nikada nisam vidio ni muško ni žensko ljepšeg $i$ prijatnijeg lica od Osmana b. Affana. ${ }^{41}$

Inače, Osmana, r.a., karakterizirale su dvije vrline: stid i darežljivost. Allahov Poslanik, s.a.v.s., nije prekrivao stegno kada su mu ušli Ebu Bekr i Omer, r.a., ali kada je ušao Osman, r.a., Muhammed, s.a.v.s., prekrio je stegno, a na upit Aiše, r.a., što je tako postupio, a nije to učinio kada su ušli Omer i njezin otac, r.a., Vjerovjesnik, s.a.v.s., odgovori: Zar da se ne zastidim čovjeka koga se stide meleki?! ? $^{42}$

Njegova darežljivost bila je paradigmatična. Sjetimo se samo priprema za Bitku na Tebuku. Vjerovjesnik, s.a.v.s., zatražio je od ashaba da naoružaju one borce koji nisu u stanju to učiniti, pa je Osman, r.a., bez dvoumljenja opremio 1.000 boraca kupivši 950 deva i 50 konja, a onda donio 1.000 zlatnika i stavio ih u Poslanikovo, s.a.v.s., krilo, nakon čega je Poslanik, s.a.v.s., izjavio: Od danas Osmanu neće ništa štetiti, ma šta uradio.! ${ }^{43}$

$\mathrm{Ne}$ zaboravimo, također, njegovu darežljivost u vrijeme gladi koja je zahvatila Medinu. Upravo u to vrijeme njegova karavana od

\footnotetext{
${ }^{40} \mathrm{O}$ trijumfalnim osvajanjima u vrijeme Osmana, r.a., pogledaj: El-Bidaje ve-nnihaje, 7/143-147; Tarihu-1-hulefai, str.143-146 i Et-Tarihu-1-islami, 3/229-235.

41 Tarihu-l-hulefai, str. 140.

${ }^{42}$ Hadis bilježe Buhari i Muslim od Aiše, r.a.

${ }^{43}$ Hadis bilježi Tirmizi. O ovom događaju vidi više: Tarihu-l-hulefai, str. 141-142; Et-Tarihu-1-islami, 3/223 i Safijjurrahman el-Mubarekfuri, Er-Rehiku-1-mahtum, str. 433.
} 
1.000 deva, natovarena raznim namirnicama, stigla je u ovaj grad. Trgovci su pohrlili Osmanu, r.a., i nudili mu duplu cijenu za te namirnice kako bi ih preprodavali ogladnjelom stanovništvu Medine. On je tražio više od toga. Oni su mu davali tri, četiri, pa i pet puta više nego što ta roba vrijedi. On im je rekao da ima jedan koji daje deset puta više. Oni su se iznenadili i pitali ko je taj. Osman, r.a., mirno je odgovorio da je to Allah, koji obećava za dobro učinjeno djelo najmanje desetostruku nagradu. Onda je svu robu i namirnice koje su dopremljene na hiljadu njegovih deva iz Sirije podijelio besplatno siromašnim i potrebnim Medinjanima! To je gest koji govori više od najvatrenijeg govora i da'vetski metod djelotvorniji od bilo kojeg drugog! Nije, onda, čudo što je Osman, r.a., bio toliko omiljen u narodu i što je mogao tako brzo i jednostavno utjecati na ljude!

Dovoljno je citirati Vjerovjesnikov, s.a.v.s., hadis koji prenosi Talha b. Ubejdillah, r.a.: Svaki vjerovjesnik je imao druga, a moj drug u Džennetu biće Osman! ${ }^{44}$

Alija, r.a.

Za vrijeme hilafeta Alije b. ebi Taliba, r.a., ${ }^{45}$ da'vetska aktivnost poprilično je reducirana i bila je, donekle, samo upražnjavana u mjestima koja su već ranije ušla u islam. Novih osvajanja nije bilo zbog novonastalih razmimoilaženja među samim muslimanima. Naime, ubistvo Osmana, r.a., bilo je prvi ozbiljniji udarac stabilnoj islamskoj državi.

\footnotetext{
${ }^{44}$ Hadis bilježi Tirmizi i ocjenjuje ga kao munkati'.

${ }^{45}$ Njegovo ime je Ali b. ebi Talib b. Abdi-1-Muttalib b. Hašim b. Abdi Menaf Ebu-1Hasan el-Kureši el-Hašimi. Rođen je 23. god. pr. Hidžre. Bio je amidžić Allahovog Poslanika, s.a.v.s, i mlađi 30 god. od njega. Prema većini izvora imao je samo deset godina kada je prešao na islam. Među onima je koji nisu ni jednog momenta obožavali kipove.

Oženio se Poslanikovom kćerkom Fatimu, r.a., i imao s njom petero djece: Hasana, Husejna, Muhsina, Zejneb i Ummu Kulsum. Bio je poznat kao jedan od najvećih umova među ashabima i jedan od najhrabrijih ljudi svoga vremena.

$\mathrm{Na}$ njega je atentat izvršio haridžija Abdurrahman b. Muldžim el-Humjeri, 40. god. po Hidžri, pa je od posljedica tog atentata nakon tri dana umro u 63. god. života. (Širu biografiju vidi: El-Bidaje ve-n-nihaje, 7/211-343; El-Isabe fi temjizi-s-sahabe, 2/507-510; Tarihu-l-hulefai, str. 155-175; dr. Faruk Hamade, cit. djelo, str.72-73; Hilmi Ali Ša'ban, cit. djelo, str. 71-93 i Muhammed Muvaffak Selima, cit. djelo, str. 29-35)
} 
Židovska svijest o pokušaju razaranja jedinstvenog islamskog tkiva, personificirana u ličnosti Abdullaha b. Sebe'e, ubaciće prvu klicu razdora među muslimanima. ${ }^{46}$ Atentat na Osmana, r.a., bit će, ustvari, jedan od razloga različitog shvatanja ovog problema među samim ashabima. Kada se tome doda do tada neviđena propaganda židova, licemjera i drugih neprijatelja islama, onda nije ni čudo što je to izazvalo takva neslaganja i razmirice.

Iako je Alija, r.a., štitio Osmana, r.a., čak je i svoja dva sina Hasana i Husejna, r.a., poslao da brane Osmana, r.a., od nezadovoljnika i buntovnika, ${ }^{47}$ ipak je od nekih optužen za to ubistvo i to će dovesti do dvije velike bitke, nažalost, između muslimana: Bitke kod Deve 36. g. i Bitke na Siffinu 37. g. po Hidžri, kojom prilikom će poginuti 110.000 muslimana! ${ }^{48}$

Jedan od razloga nesporazuma između muslimana sigurno je i odlazak velikog broja poznatih ashaba u razna područja daleko od Medine.

On je, r.a., bio jedan od najpoznatijih ljudi, nakon Poslanika, s.a.v.s., po čestitosti, pobožnosti i skromnosti. Bio je neporočan, a u sebi nije nosio nikakvo zlo i mržnju. Njegov govor i postupci bili su pravi odraz onoga što je nosio u sebi. Bio je jedan od najučenijih ashaba, kome su se obraćali za rješavanje šerijatskopravnih pitanja. A kako i ne bi bio takav kada je odgojen u kući Allahovog Poslanika, s.a.v.s., kome je on rekao, kako prenosi El-Bera' b. Azib, r.a.: Ti si moj, a ja sam tvoj! $4^{49}$

Njegova hrabrost bila je poslovična. Nikada nijedan dvoboj nije izgubio. Poslanik islama, s.a.v.s., mnogo ga je volio i imao povjerenja u njegovu snagu, znanje i vjeru. Možda se intezitet te ljubavi najbolje mogao osjetiti na dan Bitke na Hajberu, kada je Allahov Poslanik, s.a.v.s., poslao Ebu Bekra, r.a., sa zastavom na neka utvrđenja, koja on nije osvojio, pa je, nakon toga, Poslanik, s.a.v.s., rekao: Sutra ću dati zastavu čovjeku koji voli Allaha i Njegovog Poslanika! Allah će mu sigurno dati pobjedu! Zatim je pozvao Aliju,

\footnotetext{
${ }^{46}$ O planiranim akcijama koje je započeo ovaj židov vidi šire: Et-Tarihu-l-islami, 3/242-248.

${ }^{47}$ Vidi o tome: Et-Tarihu-1-islami, 3/253.

48 Šire o tome: El-Bidaje ve-n-nihaje, 7/218-221 i 239-261 i Et-Tarihu-1-islami, 3/274-277.

${ }^{49}$ Hadis bilježi Tirmizi i ocjenjuje ga: hasen-sahih.
} 
koji je imao upalu oka, pa mu je oko navlažio pljuvačkom i rekao: Uzmi ovu zastavu i idi dok ti Allah ne dadne pobjedu! $!^{50}$

O junaštvu u toj bici govori Džabir b. Abdullah, r.a., koji kaže da je Alija, r.a., uzeo vrata sa tvrđave Hajbera i stavio ih na leđa. Preko tih vrata su se ostali borci penjali i osvojili tvrđavu. Nakon toga vukli su ta vrata, ali ih niko nije mogao podignuti. Trebalo je 40 ljudi da ih dignu! $!^{51}$

Hrabrost i ljubav koju je pokazivao prema Allahovom Poslaniku, s.a.v.s., najbolje ilustrira njegova smjelost da ostane u Poslanikovoj, s.a.v.s., postelji one noći kada je Poslanik, s.a.v.s., sa svojim vjernim drugom Ebu Bekrom, r.a., učinio hidžru u Medinu i kada je te noći spreman atentat na njega! Iz tog primjera jasno se da primijetiti da se Alija, r.a., kao iskreni da'ija, žrtvovao za svoga vođu, budući da je u spasu vođe i spas da'vetske misije, a u njegovom uništenju je i uništenje ideje u koju se poziva. Međutim, Alija, r.a., nije mario za to, već je njegova glavna preokupacija bila da vođa misije bude spašen! $!^{52}$

Alija, r.a., imao je brojne vrline koje su bile itekako značajne u njegovom da'vetskom radu. Njega su čak krasile i neke vrline koje drugi ashabi nisu imali, kao što tvrdi Abdullah b. Abbas, r.a.: Alija je posjedovao 18 vrlina koje nije posjedovao niko od pripadnika ovoga ummeta! ${ }^{53}$

Otuda nije ni čudo što je najviše predaja došlo o ovom velikanu među ashabima, kao što ističe imam Ahmed: Ni o jednom ashabu Allahovog Poslanika, s.a.v.s., nije bilo toliko predaja u kojima se spominju vrline tog ashaba, koliko je došlo u predajama o Aliji! ${ }^{54}$

Nemoguće je u kratkim crtama nabrojati sve kvalitete ovog islamskog velikana. Dovoljno je i ovih nekoliko rečenica da nam ukažu na genijalnost i vrijednost ovog ashaba. Šteta je samo što je on hilafet, koji je trajao pet godina $\mathrm{i}$ tri i po mjeseca, ${ }^{55}$ proveo u najnemirnijem periodu islamske države kada su kulminirale međusobne razmirice, izuzetni nesporazumi i velika anarhija.

\footnotetext{
${ }^{50}$ Hadis bilježi Buhari i dr.

${ }^{51}$ Ovu nevjerovatnu predaju bilježi Ibn Asakir. Uporedi: Tarihu-l-hulefai, str. 156.

${ }^{52}$ Dr. Mustafa es-Siba'i, Poslanikov životni put, str. 36.

53 Tarihu-l-hulefai, str. 161.

${ }^{54}$ Ovu predaju bilježi Hakim en- Nejsaburi. Uporedi, također: Tarihu-l-hulefai, str. 157.

${ }^{55}$ El-Isabe fi temjizi-s-sahabe, 2/510.
} 
Da je situacija bila drugačija, šta bi tek ovaj genije izoštrenog intelekta, visokih moralnih kvaliteta i proslavljeni junak mogao još učiniti na planu da'veta!!!

\section{Da'va ostalih ashaba}

Budući da su ashabi učili izravno od Allahovog Poslanika, s.a.v.s., jasno je da su najbolje savladali metode da'vetskog angažiranja. Da jedna generacija može sebe iz temelja preobraziti i transformirati na način kako to zahtijeva Gospodar univerzuma, ekspilicite se da primijetiti iz slučaja prve generacije muslimana. Oni to priznanje, koje su, neosporno je, zaslužili, dobivaju direktno od Plemenitog Allaha: Vi ste narod najbolji od svih koji se ikada pojavio: tražite da se čine dobra djela a od nevaljalih odvraćate, $i$ u Allaha vjerujete. ${ }^{56}$

To je fenomen pred kojim treba da zastane svaki pojedinac i da ga analizira. U čemu je tajna njihova uspjeha?! Zbog čega se generacija poput ove, u tako impozantnom broju i takvoga kvaliteta, nikada više nije ponovila tokom historije?!Ako analiziramo razloge njihovog uspjeha, doći ćemo do saznanja da je njihov veliki uspjeh došao nakon ispunjavanja sljedećih elemenata:

1. čišćenjem svojih bića od natruha bilo kakvih neislamskih elemenata, radu sa sobom i drugima unutar svoje zajednice;

2. nesebičnim materijalnim davanjima na Allahovom putu, posebno za opremanje boraca koji su Allahovu nepatvorenu riječ širili u nova područja i oslobađali podjarmljene narode i omogućavali im da saznaju istinu;

3. vlastitom borbom, žrtvujući svoje zdravlje, tijela i živote u želji da Alahova riječ zadominira i bude temeljem ljudskih zakona.

Navedimo samo neke primjere koji jasno govore o toj neponovljivoj generaciji koja je primjer svim generacijama koje dolaze.

${ }^{56}$ Alu Imran, 110. 
Bilal b. Rebbah, r.a.

Pogledajmo Bilala b. Rebbaha, r.a., ${ }^{57}$ koji podnosi najteža mučenja i najsvirepija maltretiranja na putu istine. Umejje b. Halef, robovlasnik koji ga posjeduje, koristi sve metode mučenja kako bi ga odvratio od puta kojim je krenuo, ali u tome ne uspijeva. Bilal, r.a., nakon oslobađanja iz ropstva, postaje gorljivi da'ija, koji će, pozivajući ljude ezanom na namaz, pozivati i u vjeru upotrebljavajući pri tome najraznovrsnije da'vetske metode.

Jasir, r.a., i njegova porodica

Jasirova, r.a., porodica primjer je istinske žrtve na Allahovom putu samo zbog ideje koju interpretira. Jasir, r.a. ${ }^{58}$ umro je pod torturama idolopoklonika, Sumejja, r.a., ${ }^{59}$ prva žena-šehid u islamu, probodena je kopljem (ubio ju je Ebu Džehl) zato što nije na putu istine posustala! Njihov sin Ammar, r.a. ${ }^{60}$ neustrašivi je borac koji će podnijeti velike žrtve sa svojom porodicom i na kraju, za vrijeme hilafeta Alije, r.a., pasti kao šehid! Abdullah b. Dža'fer prenosi da je Allahov Poslanik, s.a.v.s., prolazeći pored ove porodice koja je bila mučena, ne mogavši ništa uraditi, samo rekao: Strpljenje, porodico Jasirova, strpljenje, jer, doista, vaš sastanak će u Džennetu biti! $!^{61}$

${ }^{57}$ Bilal b. Rebbah el-Habeši, porijeklom iz Abesinije. Bio je Poslanikov, s.a.v.s., mujezzin, iako je bio crnac. Učestvovao je sa njim u svim bitkama. Umro je od kuge u Siriji za vrijeme hilafeta Omera b. el-Hattaba, r.a., kada je bio u džihadu. (Vidi njegovu biografiju: Ebu Nu'ajm, Hil'jetu-l-evlija', 1/147-151; Ibn Abdi-l-Berr, ElIsti'ab fi esmai-l-ashab, 1/141-144 i Ibn Hadžer, El-Isabe fi temjizi-s-sahabe, 1/165)

${ }^{58}$ Jasir b. Amir b. Malik el-Anesi porijeklom je iz Jemena. On je među prvima sa svojom ženom Sumejjom, r.a., i sinom Ammarom, r.a., primio islam. (Vidi: El-Isabe fi temjizi-s-sahabe, 3/647-648)

${ }^{59}$ Sumejja bint Hubat, u nekim verzijama bint Habt, iako je u vrijeme primanja islama bila slabašna starica, kako navodi Ibn Hadžer, ipak je pokazala svoju hrabrost i izdržljivost. (Vidi: El-Isabe, 4/334-335)

${ }^{60}$ Ammar b. Jasir b. Amir Ebu-l-Jakzan el-Anbesi. Sudjelovao je sa Poslanikom, s.a.v.s., u svim bitkama. U Bici na Jemami odrezano mu je uho u jeku borbe. U Bici na Siffinu 37. g. po Hidžri, boreći se na strani Alije, r.a., pao je kao šehid, kako je i najavio Poslanik, s.a.v.s. Tada je Ammar, r.a., imao preko 90 godina! (Njegovu biografiju vidi: Hil'jetu-l-evlija', 1/139-143; El-Isti'ab, 2/476481 i El-Isabe, 2/512513)

${ }^{61}$ Hadis bilježi Ahmed u Ez-Zuhdu, Hakim u El-Mustedreku, Taberani u ElMu'džemu-l-evsatu i dr. 
Suhejb er-Rumi ${ }^{62}$ ostavlja sav svoj imetak Mekkelijama, koji ga ne dozvoljavaju iznijeti, u zamjenu za vjeru koju želi spasiti. Kada je stigao u Medinu, dočekao ga je Poslanik islama, s.a.v.s., rekavši mu: Ebu Jahja, trgovina ti je uspjela! ${ }^{63}$ Njegovo žrtvovanje ogromnog materijalnog bogatstva za islam bilo je povod objavljivanju kur'anskog ajeta: Ima ljudi koji se žrtvuju da bi Allaha umilostivili - a Allah je milostiv robovima Svojim. ${ }^{64}$

Sa'd b. ebi Vekkas, r.a.

Primjer Sa'd b. ebi Vekkasa, r.a., ${ }^{65}$ velikog mudžahida, najboljeg strijelca među Kurejšijama i prvoga koji je upotrijebio strijelu na Allahovom putu, manifestira nam poslovičnu ljubav prema islamskoj misiji kojoj je pristupio. Čak ni njegova majka nije tu ljubav mogla zasjeniti! Sa'd, r.a., kaže: Bio sam dobar prema svojoj majci. Međutim, kada sam prešao na islam, rekla mi je: „Ili ćeš ostaviti tu svoju vjeru, ili ja neću ni jesti ni piti, sve do smrti, pa će ti narod govoriti: 'Ubico svoje majke!'" Majka tri dana niti je jela niti je pila, pa je izgledala prilično iznureno. Vidjevši je, Sa'd joj se obraća riječima: Majko, neka znaš, tako mi Allaha, kada bi imala hiljadu duša, pa ti sve jedna za drugom izlazila, ja ovu svoju vjeru ne bih ni

${ }^{62}$ Suhejb b. Sinan b. Malik ebu Jahja er-Rumi bio je porijeklom Arap, ali su ga Vizantinci još kao dijete zarobili i prodali. Prešao je na islam zajedno sa Ammar b. Jasirom, r.a., dok se još Vjerovjesnik, s.a.v.s., tajno sastajao sa prvim muslimanima u Erkamovoj, r.a., kući. Umro je 38. god. po Hidžri u 70. god. života. (Vidi: Hil'jetu-1-evlija', 1/151-156; El-Isti'ab, 2/174-182 i El-Isabe, 2/195-196.)

${ }^{63}$ Hadis bilježi Hakim i kaže da je vjerodostojan prema uvjetima imama Muslima. (Vidi: El-Mustedrek, 3/398)

${ }^{64}$ El-Bekare, 207. Vidi o tome: Tenviru-1-mikjas min tefsir Ibn Abbas, str. 28; ElKurtubi, El-Džami'u li ahkami-1-Kur'an, 3/23-24; Dr. Sulejman el-Eškar, Zubdetu-ttefsir min Fethi-1-kadir, str. 40; Dr. Jusuf Ramić, Povodi objave Kur’ana, str. 43-44.

${ }^{65} \mathrm{Sa}$ 'd b. Malik b. Vuhejb b. Abdi Menaf el-Kureši. Bio je izuzetna ličnost kakvih je historija malo poznavala. Prešao je na islam sa 17 godina. Bio je veliki mudžahid. $\mathrm{Na}$ čelu je onih koji osvajaju Irak, Ktesifon i Kadisijju. Nakon razmimoilaženja među muslimanima, poslije ubistva Osmana, r.,a., izoluje se od svijeta i umire u Akuku, pored Medine, 55. god. po Hidžri. (Vidi šire u: Hil'jetu-l-evlija', 1/92-95; El-Isti'ab, 2/18-27; El-Isabe, 2/33-34; Ashabi Allahovog Poslanika, str. 133-143 i Deseterica kojima je obećan džennet, str. 69-76) 
za šta ostavio!!! Ako hoćeš jedi, a ako nećeš, ne moraš! Kada je to majka vidjela, počela je jesti! ${ }^{66}$

Sa'd, r.a., nastavljajući kaže: Allah je objavio ovaj ajet $u$ povodu ovog mog slučaja:

A ako te budu nagovarali da drugog Meni ravnim smatraš, onome o kome ništa ne znaš, ti ih ne slušaj i prema njima se, na ovom svijetu, velikodušno ponašaj, a slijedi put onoga koji se iskreno Meni obraća; Meni ćete se poslije vratiti i Ja ću vas o onome što ste radili obavijestiti. ${ }^{67}$

Enes b. Nadr el-Ensari

Enes b. Malik, r.a., prenosi da se njegov amidža, Enes b. Nadr el-Ensari, r.a., ${ }^{68}$ u najvećem jeku Bitke na Uhudu, obratio Sa'du b. Mu'azu, r.a., riječima: Sa'de, tako mi Onoga u čijoj je ruci moj život, doista osjećam miris Dženneta u podnožju Uhuda! ${ }^{69}$ Onda se hrabro i dostojanstveno borio dok nije poginuo.

Enes, r.a., pripovijeda da su ga našli među šehidima Uhuda, a na njegovom tijelu je bilo preko 80 rana od sablji, kopalja i strijela! Nisu ga uopće mogli prepoznati. Sestra ga je jedva prepoznala po mladežu na prstima! ${ }^{70}$ Tada je, zbog njega i njegovih drugova, objavljen ajet: Ima vjernika koji ispunjavaju zavjet dat Allahu, ima ih koji su poginuli, i ima ih koji to očekuju - nisu ništa izmijenili. ${ }^{71}$

Od ashaba koji su bili povod ovom ajetu su, prema ElKurtubiju, Talha b. Ubejdillah i Mus'ab b 'Umejr, r.a. ${ }^{72}$ Ibn Abbas,

\footnotetext{
${ }^{66}$ Ovu predaju bilježe Muslim, Tirmizi i Ahmed.

${ }^{67}$ Lukman, 15. O ovome vidi: Tefsir Ibn Abbasa, str. 344-345; Tefsir Ibn Kesir, str. 1042 (izdanje na bosanskom jeziku); Dr. Jusuf Ramić, cit. djelo, str. 179 i Muhammed Muveffak Selima, cit. djelo, str.71.

${ }^{68}$ Enes b. en-Nadr b. Damdam b. Zejd el-Ensari nije učestvovao u Bici na Bedru. Priželjkivao je novu priliku u kojoj može pokazati svoju hrabrost i umješnost. Allah je odredio da bude veliki šehid Uhuda. (Vidi: El-Isti'ab, 1/70-71)

${ }^{69}$ Hadis bilježi Buhari, Muslim i Tirmizi.

70 El-Isti'ab, 1/71; Tefsir el-Kurtubi, 14/156-157; Tefsir Ibn Kesir, str. 1064. (izdanje na bosanskom) i Dr. J. Ramić, cit. djelo, str. 182-183.

${ }^{71}$ El-Ahzab, 23.

${ }^{72}$ Vidi: Tefsir el-Kurtubi, 14/156-157.
} 
r.a., smatra da je ovaj ajet spušten u povodu hrabrosti i pogibije Hamze, r.a. ${ }^{73}$

'Umejr b. Humam, r.a.

Na putu da've, njenog afirmiranja i širenja ashabi nisu štedjeli svoje živote. To najbolje ilustrira primjer Umejra b. Humama, r.a., ${ }^{74}$ koji je Vjrovjesnika, s.a.v.s., kada se pred Bitku na Bedru obratio ashabima riječima: Krenite ka Džennetu koji je prostran kao nebesa $i$ Zemlja, upitao ga: Allahov Poslaniče, zar je Džennet prostran kao nebesa i Zemlja?! Vjerovjesnik, s.a.v.s., odgovori : Da! To je 'Umejr, r.a., popratio sa: Beh, beh! Poslanik, s.a.v.s., ga je, nakon toga, upitao šta misli pod tim, a on mu je odgovorio: Ništa drugo nego da budem jedan od stanovnika Dženneta! Vjerovjesnik, s.a.v.s., mu je rekao: Ti si jedan od njegovih stanovnika! Tada je 'Umjer, r.a., bacio hurme koje je počeo jesti komentarišući: Ako budem živio toliko dugo koliko traje jedenje ovih hurmi, biće to isuviše dug život! Bacio je hurme i borio se na Allahovom putu dok nije pao kao šehid! ${ }^{75}$

Talha b. 'Ubejdillah, r.a.

Talha b. Ubejdillah, r.a., ${ }^{76}$ prešao je na islam u 15. godini života i od tada pa sve do svoje smrti bio je borac za afirmiranje islamske ideje. Njegova darežljivost prelazila je granice vjerovatnog! $\mathrm{U}$ jednom danu je podijelio sadaku od 100.000 srebrenjaka. Drugom prilikom je podijelio sirotinji svu svoju imovinu, koja je bila ogromna! Sebi nije ostavio ništa! ${ }^{77}$ Džabir b. Abdullah, r.a, kaže: Nisam vidio da ijedan čovjek, mimo Talhe, daje više imetka, a da mu ga niko i ne traži! ${ }^{78}$

${ }^{73}$ Uporedi: Tenviru-1-mikjas, tefsir Ibn Abbas, str. 352.

${ }^{74}$ Umejr b. Humam b. el-Džemuh el-Ensari bio je prvi ashab koji je pao kao šehid u borbi. To se desilo u Bici na Bedru. (Vidi: El-Isabe, 3/31)

${ }^{75}$ Hadis bilježi Muslim.

${ }^{76}$ Talha b. Ubejdillah b. Osman et-Tejmi je među prvom osmericom prešao na islam. Jedan je od deseterice kojima je obećan Džennet. Bio je jedan od heroja islama. Posebno se njegovo junaštvo pokazalo u Bici na Uhudu. Poginuo je u Bici kod Deve 36. god. kada je bio u zaštiti Aiše, r.a. Ukopan je u Basri. (Vidi: Hil'jetu-1evlija, 1/87-89; El-Isti'ab, 2/219-225 i El-Isabe, 2/229-230)

${ }^{77}$ Vidi o tome: Muhammed Muveffak Selima, cit. djelo, str. 41.

${ }^{78}$ Hilmi Ali Ša’ban, cit. djelo, str. 181. 
U Bici na Uhudu zadobio je 24 rane po tijelu i prstima. Štiteći Poslanika, s.a.v.s., postavio je svoju ruku, pa mu je od zadobijenog udarca paralizovan prst. $^{79}$ Sa koliko žara i požrtvovanja je štitio Poslanika, s.a.v.s., najbolje kazuju riječi Ebu Bekra, r.a., koji je izjavio: Taj dan Bitke na Uhudu bio je Talhin dan! $!^{80}$ Otuda je Allahov Poslanik, s.a.v.s., rekao: Kome je drago vidjeti šehida kako hoda zemljom, neka gleda Talhu $b$. Ubejdillaha! $!^{81}$

Ez-Zubejr b. el-'Avvam, r.a.

Ez-Zubejr b. el-Avvam, r.a., ${ }^{82}$ bio je prva sablja u islamu, pomagač Poslanika, s.a.v.s., jedan od heroja koji je dokrajčivao neprijatelja čak i golim rukama! Djeci je dao imena šehida želeći da i oni padnu kao šehidi. ${ }^{83}$

On je, r.a., u Bici na Jermuku bio vođa jednog odreda. Budući da je vizantijska vojska bila daleko jača i opremljenija i da su muslimani počeli pomalo uzmicati, Zubejr, r.a., sa tekbirom na usnama, sam navali na neprijatelja udarajući svojom sabljom, koseći sve pred sobom, dolazi do kraja njihovog ešalona, a onda se, pred zbunjenim i muslimanskim i neprijateljskim vojnicima, vrati ponovo udarajući neprijatelja. Tada muslimani dobiše snagu i svi jurnuše na neprijatelja i ubjedljivo ga poraziše! ${ }^{84}$

On nije bio nenadmašan ne samo u borbi već i u dobročinstvu! Baveći se trgovinom stekao je ogromno bogatstvo, toliko da je broj službenika koji su se brinuli o njegovom kapitalu dostigao hiljadu!!! Međutim, ništa od tog kapitala nije ulazilo u njegovu kuću! Sve je

79 O njegovoj izuzetnoj hrabrosti vidi: Grupa autora, Šebabun havle-r-Resul, str. 271-272 i dr. Abdurrahman Ra'fat el-Baša, Iz života ashaba, str. 340-341.

80 Šebabun havle-r-Resul, str. 271.

${ }^{81}$ Hadis bilježi Ebu Nu'ajm u Hul'jetu-l-evlija', 1/88.

${ }^{82}$ Ez-Zubejr b. el-Avvam b. Huvejlid ebu Abdullah el-Kureši je prešao na islam, kao i Talha, sa 15 godina, zalaganjem Ebu Bekra, r.a. Zbog svoje vjere bio je maltretiran i od svoje porodice. Učestvovao je sa Poslanikom, s.a.v.s., u svim bitkama za afirmaciju islama. Jedan je od deseterice kojima je obećan Džennet. Ubijen je kukavički, dok je klanjao namaz, u 64. god. života, od strane Amra b. Džemruza etTemimija. (Vidi: En-Nesai, Fadailu-s-sahabe, str. 114-116; Hil'jetu-levlija', 1/8992; El-Isti'ab, 1/580-585 i El-Isabe, 1/545-546)

${ }^{83}$ Vidi: Hilmi Ali Ša'ban, cit. izvor, str. 148-149.

${ }^{84}$ Vidi šire: nav. djelo, str. 148. 
dijelio na Allahovom putu, onima koji su potrebni! Čak je, i pored takvog bogatstva, dijeleći, umro u dugu!!! ${ }^{85}$

Ebu 'Ubjede b. el-Džerrah, r.a.

Ebu Ubejde b. el-Džerrah, r.a., ${ }^{86}$ junak sa Uhuda, dobio je nadimak Krezubi, zato što je izgubio dva zuba kada je htio Poslaniku, s.a.v.s., bezbolno izvaditi dva metalna dijela oklopa koji su mu se u borbi zabili u lice

Njegovo možda najveće iskušenje bilo je na Bedru. To je bila najbolja legitimacija njegovog granitnog imana i preferiranja Allaha i Njegove vjere u odnosu na sve, pa čak i na svoga oca! On je, naime, u toj bici izbjegavao svoga oca koji se borio na strani idolopklonika, ali kada sukob nije mogao izbjeći, ubio je i svog oca!!! ${ }^{87}$

Se'id b. Zejd, r.a.

Ako čitate biografiju bilo kojeg ashaba, naići ćete na slične primjere. Pogledajmo biografiju Se'id b. Zejda, r.a., jednog od deseterice kojima je Džennet zagarantiran, koji je želeći da što više doprinese islamu imao čak 31 dijete: 13 sinova i $18 \mathrm{kćeri},{ }^{88}$ a uz to je, najviše da'vetski djelovao na Omera, r.a., zajedno sa svojom ženom Fatimom, r.a., Omerovom, r.a., sestrom i Habbabom b. el-Erettom, r.a., da pređe na islam. Bio je jedan od junaka bitke protiv Musejleme el-Kezzaba, lažnog poslanika. Za vrijeme Bitke na Jermuku bio je namjesnik Damaska. Ostavlja položaj i odlazi u tu bitku i pokazuje izvanrednu hrabrost! ${ }^{89}$

\footnotetext{
${ }^{85}$ Vidi: Isti izvor, str. 151.

${ }^{86}$ Ebu Ubejde Amir b. Abdullah b. el-Džerrah je islam primio dan nakon Ebu Bekra, r,a. Jedan je od deseterice kojima je zagarntiran Džennet. Učinio je hidžru u Abesiniju. Poznat je po svojoj hrabrosti i povjerljivosti. Allahov Poslanik, s.a.v.s., zbog toga ga je nazvao Povjerenikom ummeta. U Šamu je predvodio četiri vojske koje je poslao Ebu Bekr, r.a. Umro je od kuge u Šamu kada je predvodio vojsku 18. god. po Hidžri. Tada je imao 58 godina. (Vidi: En-Nesai, Fadailu-s-sahabe, str. 106110; Hil'jetu-l-evlija', 1/100-102; El-Isti'ab, 3/2-4 i El-Isabe, 2/252-254)

${ }^{87}$ Vidi: Ibn Hadžer, Fethu-1-bari, 7/117.

${ }^{88}$ Vidi: Muhammed Muveffak Selima, cit. djelo, str. 56.

${ }^{89}$ Pogledaj: Fadailu-s-sahabe, str. 105-106; Hil'jetu-l-evlija', 1/95-97 i El-Isabe, $2 / 46$.
} 
Hamza b. 'Abdulmuttalib, r.a.

Lav islama i predvodnik šehida Hamza b. Abdulmuttalib, r.a., svoju je hrabrost pokazao u Borbi na Uhudu, kada je ubio oko 30 idolopoklonika i postao simbol junaštva do Sudnjega dana! ${ }^{90}$

El-Bera' b. Malik, r.a.

El-Bera' b. Malik, r.a., boreći se u području između Iraka i Perzije u bici za Ehvaz, samo u dvobojima ubio je 100 perzijskih vojnika, ne računajući one koji su u borbi poginuli od njegove sablje! Njegova hrabrost na putu širenja islama i rušenja onih koji devalviraju istinu najupečatljivije se pokazala u bici protiv Musejleme elKezzaba, kada je jurišajući na neprijatelja uspio otvoriti vrata utvrđenja i time doprinijeti pobjedi muslimana, kojom prilikom je zadobio više od 80 rana! $^{91}$

Seleme b. el-Ekve'a, r.a.

Zastanimo bar na trenutak nad svijetlim primjerima Seleme b. el-Ekve'a, r.a., junaka sa Hajbera, koji se u Bici Zi Kird sam suprotstavio čitavoj neprijateljskoj vojsci, dok mu u pomoć, kasnije, nije pristigla muslimanska vojska! ${ }^{92}$

'Amr b. Ma'dikerib, r.a.

Pogledajmo junaka sa Kadisijje, Amra b. Me'dikeriba, r.a., koji se junački borio u bici za Nehavend, a imao je preko 90 godina!!! ${ }^{93}$

Usame b. Zejd, r.a.

Bio je dječak u Bici na Hendeku i tada imao samo 15 godina, a lavovski se borio i bio ravnopravan daleko starijim borcima od sebe!

\footnotetext{
${ }^{90}$ Vidi: El-Isti'ab, 1/271-276.

${ }^{91}$ Vidi: El-Isabe, 1/143-144 i Ashabi Allahovog Poslanika, str. 301.

92 Pogledaj naslov: Junak vrijedan kao odred, u knjizi: Ashabi Allahovog Poslanika, str. 288-291.

${ }^{93}$ Vidi: isti izvor, str. 420.
} 
Ovu hrabrost mogao je svako od njih emanirati samo iz islama. Tu darežljivost mogla je iznjedriti samo čvrsta vjera i svijest o nagradi na budućem svijetu. Tu da'vetsku angažiranost mogla je potaknuti škola Allahovog Poslanika, s.a.v.s., nastala u kući El-Erkama b. ebi elErkama, r.a.

Mus'ab b. 'Umjer, r.a.

Mus'ab b. 'Umjer, r.a., ${ }^{94}$ bio je jedan od najmarljivijih učenika Allahovog poslanika Muhammeda, sallallahu 'alejhi ve sellem. Veoma rano je primio islam i u njega je utkao svu svoju fizičku i duhovnu snagu koju je posjedovao. Iako su ga roditelji maltretirali zbog njegove odanosti islamu kroz zabranu hrane, pića i odijevanja, on je ostao stamen na putu istine i postao primjer drugim mladićima kako se bori za ideale koji nadvisuju ovodunjalučki život i životne potrebe.

Metode koje je upotrijebio u svom da'vetskom angažmanu postale su paradigma svim budućim generacijama. On je, naime, pronicljivom selekcijom preveo na islam dva ključna čovjeka $u$ Medini i, na taj način, omogućio prelazak polovine stanovnika tog grada na islam, ali i otvorio vrata za normalan dolazak muhadžira iz idolopokloničke Mekke u ovaj grad, koji će postati nukleus iz kojega će se izroditi nova, jedinstvena, neponovljiva generacija muslimana do Sudnjega dana.

Za formiranje prve islamske zajednice, vojske i države itekako je doprinio ovaj prvi ambasador da've u islamu, kojeg je Allahov Poslanik, sallallahu 'alejhi ve sellem, poslao da prve muslimane Medine poučava učenju Kur'ana i temeljnim postulatima islama.

Analiziranje njegove perfektne metode, savladane $u$ Poslanikovoj, sallallahu 'alejhi ve sellem, školi uveliko će nam doprinijeti da pokušamo na sličan način drugima predstaviti i prikučiti

\footnotetext{
${ }^{94}$ Mus'ab b. 'Umejr b. Hašim b. 'Abdi Menaf b. 'Abdi-d-dar b. Kusajj b. Kilab elBedri el-Kureši el-'Abderi rođen je u Mekki. Islam je primio veoma rano i to je držao u tajnosti. Kada su roditelji saznali za njegov prelazak na islam, mučili su ga na razne načine, čak su mu zabranjivali jelo i piće, nadajući se da će se vratiti u idolopokloničku vjeru. On je sva zlostavljanja na dostojanstven način prevazišao. Imao nešto preko četrdeset godina kada je pao kao šehid na Uhudu. (Vidi o tome: Ibn Hišam, Poslanikov životopis, str. 87. i El-Mubarekfuri, Er-Rehiku-l-mahtum, str. 144)
} 
islam i afirmirati ga na način koji će postati blizak i prijemčiv onima koji za istinom žude i žele je jednoga dana spoznati.

\section{Zaključak}

Ashabi Allahovog poslanika Muhammeda, sallallahu 'alejhi ve sellem, posebnu su pažnju poklanjali da'vi i da'vetskom angažiranju. Čitajući njihove biografije primjećujemo da su svaki slobodan trenutak svoga života obilato koristili da drugima prenesu ono što su istinski osjećali u dubini svoga bića i u srži svojih kostiju. Željeli su sreću i duhovno zadovoljstvo koje su osjećali podijeliti sa drugima. Upravo ta nesebičnost, briga za druge i pokušaj da ih se izbavi iz zablude bili su i ostali njihova konstantna opsesija.

Druženje sa Allahovim Poslanikom, s.a.v.s., i svakodnevni kružoci sa njim iznjedrili su izuzetnu generaciju da'ija, koja će svojim metodama savladanim u Vjerovjesnikovoj, sallallahu 'alejhi ve selle, školi uveliko doprinijeti da se islam izuzetno brzo proširi i da temeljito izmijeni način života ogrmnog broja ljudi. Treba znati da se njihovo djelovanje nije zadržalo samo unutar granica Mekke. Njihov da'vetski angažman bio je primjetan van granica ovog grada i prije Hidžre.

Nadamo se da će nas ovo nekoliko navedenih primjera potaknuti na ozbiljniji i djelotvorniji da'vetski angažman.

\section{Korištena literatura}

1. El-Kur'ani-l-kerim (prijevod: Besim Korkut), Medina, S. Arabija, 1412.h.g.

2. Ibn 'Abdulberr, Ebu Omer el-Kurtubi, El-Isti'ab fi esmai-lashab, Daru-l-fikr, Bejrut (bez god. izdanja).

3. 'Abdurreuf, dr. Muhammed, Bilal ibn Rebbah, muezzin i ashab Božijeg poslanika Muhammeda, a.s. (prijevod: Tajjib Pašanbegović), Starješinstvo IZ u BiH, Hrvatskoj i Sloveniji, Sarajevo, 1984.

4. Ahmed, b. Hanbel eš-Šejbani, El-Musned, El-Mektebu-1islami, Bejrut, 1983.

5. El-Baša, dr. Abdurrahma Ra'fat, Iz života ashaba, AIO, Zenica, 1997. 
6. El-Bejheki, Muhammed b. Husejn, Es-Sunenu-l-kubra, Hajderabad, Indija, 1352.h.g.

7. Šu'abu-l-iman, Daru-l-kutubi-l-'ilmijje, Bejrut, 1990.

8. El-Buhari, Muhammed b. Isma'il, Buharijina zbirka hadis (prijevod i komentar: Hasan Škapur), Odbor IZ Prijedor, 1974.

9. Es-Sahih, Daru ihjai-t-turasi-1-'arebi, Bejrut (bez god. izdanja).

10. Ed-Darekutni, 'Ali b. Omer, Es-Sunen, 'Alemu-1-kutub, Bejrut, 1983.

11. Ebu Davud, Sulejman es-Sidžistani, Es-Sunen, Daru ihjai-ssunneti-n-nebevijjeti (bez mjesta i god. izdanja).

12. Ibnu-1-Dževzi, Ebu-1-Feredž 'Abdurrahman, Menakibu emiril-mu'minine Omer b. el-Hattab, Daru-l-kutubi-1-'ilmijje, Bejrut (bez god. izdanja).

13. Ferid, Ahmed, Bistro more pobožnosti i suptilnosti, AIO, Zenica, 1999.

14. El-Gadban, Munir Muhammed, El-Menhedžu-l-hareki li-ssireti-n-nebevijjeti, Mektebetu-1-menar, Ez-Zerka', Jordan, 1992.

15. Gajtas, Husni Muhammed Ibrahim, Ed-Da'wetu-l-islamijjetu fi 'ahdi Emiri-l-mu'minin Omer b. el-Hattab, El-Mektebu-1islami, Bejrut-Damask, 1985.

16. Ibn Hadžer, Ahmed b. 'Ali el-'Askalani, El-Isabe fi temjizi-ssahabe, Daru-l-fikr, Bejrut (bez god. izdanja).

17. El-Hakim, Ebu 'Abdullah en-Nejsaburi, El-Mustedreku 'ales-sahihajni, Daru-l-fikr, Bejrut, 1978.

18. Ibn Hišam, Poslanikov životopis (prijevod: Mustafa Prljača), Bemust, Sarajevo, 1998.

19. Es-Siretu-n-nebevijjetu, Daru-1-kitabi-1-'arebi, Bejrut, 1987.

20. Ibrahim, Sabir Abduh, Ebu Bekr prvi halifa, Udruženje ilmijje, Sarajevo, 1996.

21. Ibn Kesir, hafiz Isma'il, El-Bidaje ve-n-nihaje, Daru-1-hadis, Kairo, 1993.

22. Tefsir, Visoki saudijski komitet za pomoć BiH i Kulturni centar «Kralj Fahd», Sarajevo, 2002.

23. El-Kurtubi, Muhammed b. Ahmed, El-Džami'u li ahkami-lKur'an, Daru-l-hadis, Kairo, 1996. 
24. Ibn Madže, Muhammed el-Kazvini, Es-Sunen, Daru-l-hadis, Kairo, 1994.

25. El-Mubarekfuri, Safijjurrahman, Er-Rehiku-l-mahtum, Mektebetu dari-s-selam, Rijad, 1994.

26. Zapečaćeni džennetski napitak (prijevod: Subhija Skenderović-Hadžimejlić), Visoki saudijski komitet za pomoć narodu BiH, Sarajevo, 2000.

27. Muslim, b. Hadždžadž en-Nejsaburi, Es-Sahih, Daru Ibn Hazm, Bejrut, 1995.

28. En-Nesai, Ebu 'Abdurrahman, Fadailu-s-sahabe, Daru-ssekafe, Kazablanka, Maroko, 1984.

29. Es-Sunen, Daru-1-fikr, Bejrut (bez god. izdanja).

30. Ebu Nu'ajm, Ahmed El-Asbehani, Hil'jetu-l-evlija've tabekatu-l-asfija', Daru-1-kutubi-1-'arebi, Bejrut, 1967.

31. Ramić, dr. Jusuf, Povodi objave, Starješinstvo IZ BiH, Hrvatske i Slovenije, Sarajevo, 1984.

32. Selima, Muhammed Muveffak, Deseterica kojima je džennet obećan, Visoki saduijski komitet za pomoć BiH, Sarajevo, 1998.

33. Es-Siba'i, Dr. Mustafa, Posanikov životni put-pouke $i$ poruke, prijevod: Ahmet Alibašić (bez mjesta i god. izdanja).

34. Es-Sujuti, Dželaluddin, Tarihu-l-hulefa', Daru-1-fikr (bez mjesta i god. izdanja).

35. Ša'ban, Hilmi 'Ali, Ashabi Allahovoga poslanika, Visoki saudijski komitet za pomoć BiH, Sarajevo, 1998.

36. Šakir, Ahmed Muhammed, El-Ba'isu-l-hasis šerh ihtisari 'ulumi-l-hadis, Mektebetu dari-1-fihai - Damask i Mektebetu dari-s-selami, Rijad, 1994.

37. Šakir, Mahmud, Et-Tarihu-l-islami, El-Mektebu-1-islami, Bejrut-Damask-'Amman, 1991.

38. Et-Taberani, Ebu-1-Kasim, El-Mu'džemu-s-sagir, Daru-1kutubi-1-'ilmijje, Bejrut, 1983.

39. Et-Tirmizi, Ebu 'Isa Muhammed, Es-Sunen, Daru-1-kutubi-1'ilmijje, Bejrut (bez god. izdanja).

40. Tirmizijina zbirka hadisa, prijevod i komentar: Mahmut Karalić, Elči Ibrahim-pašina medresa, Travnik, 1999-2000. 
PROF. DR. ŠEFIK KURDIĆ, P.H.D.

\section{DAWA ENGAGEMENT OF PROPHET'S COMPANIONS}

SUMMARY

This work tackles engagement of sahabah in the field of dawa, highlighting concrete examples of their dawa engagement.

The work pays special attention to dawa engagement of the four khalips, and other sahabas like Bilal b Rebbah, Suhayb er Rumi, Saad b Ebi Waqqas and others.

Sahabah wanted to share with others happiness and spiritual pleasure they felt. Exactly this unselfishness and worry for others and attempt to save them from the misapprehension, were their constant obsessions.

With this work and mentioned examples I intended to induce to more serious and effective dawa engagement. 
الأستاذ الدكتور شفيق كوردينش

النشاط الدعوي لائى الصحابة

الملخص

يتتاول هذا البحث دور الصحابة في حقل الدعوة موضحاً الأمنلة الو اقعية لنشاطهم

الدعوي.

لقد ركز البحث على النشاط الدعوي للخلفاء الأربعة وبقية الصحابة، وخص بالذكر نشاط بلال بن رباح، صهيب الرومي، سعد بن أبي وقاص الدعوي و غير هم.

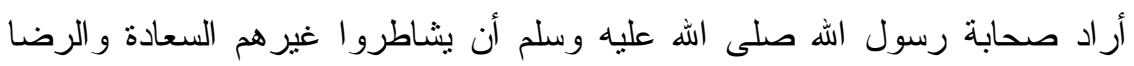
الروحي الذي تمتعو ا به، وكان الإيثار و الاهتمام بالغير و الحرص على إخر اج الناس من لن النه الضنلا همهم الدائم. هدف هذا البحث هو أن تكون بضعة الأمثلة المذكورة حافزاً للنشاط أكثر جديةً وجدوى. 